\title{
Impact of Annual Ryegrass on Nitrate-N Losses during One Growing Season of Maize in the Midwestern United States
}

-An On-Farm Case Study

\author{
Jude A. Holscher, Paul C. Davidson* \\ Department of Agricultural and Biological Engineering, University of Illinois Urbana-Champaign, Urbana, IL, USA \\ Email: *pdavidso@illinois.edu
}

How to cite this paper: Holscher, J.A. and Davidson, P.C. (2019) Impact of Annual Ryegrass on Nitrate-N Losses during One Growing Season of Maize in the Midwestern United States. Journal of Water Resource and Protection, 11, 606-625. https://doi.org/10.4236/jwarp.2019.115035

Received: April 18, 2019

Accepted: May 26, 2019

Published: May 29, 2019

Copyright $\odot 2019$ by author(s) and Scientific Research Publishing Inc. This work is licensed under the Creative Commons Attribution International License (CC BY 4.0).

http://creativecommons.org/licenses/by/4.0/

\begin{abstract}
Winter cover crops have been shown to reduce nitrate- $\mathrm{N}\left(\mathrm{NO}_{3}-\mathrm{N}\right)$ losses in runoff water and are recommended by the Illinois Nutrient Loss Reduction Strategy (NLRS) for reducing nutrient losses from agricultural fields. With an estimated 80 percent of the $\mathrm{NO}_{3}-\mathrm{N}$ load in Illinois coming from agriculture, the NLRS stresses the importance of farmers' voluntary implementation of best management strategies in order to reach these goals. This study compares the difference in $\mathrm{NO}_{3}-\mathrm{N}$ losses from tile drainage water from an annual ryegrass (AR, Lolium multiflorum) winter cover-cropped treatment to a conventional tillage (CT) control (fall chisel and spring field cultivation). Throughout the maize (Zea mays L.) growing season, tile drainage water was collected and analyzed for $\mathrm{NO}_{3}-\mathrm{N}$ concentrations. Despite the AR treatment having a $29 \%$ lower mean daily $\mathrm{NO}_{3}-\mathrm{N}$ concentration, there was no significant difference in total daily $\mathrm{NO}_{3}-\mathrm{N}$ flux between $\mathrm{AR}$ and CT for this study period of April-July 2015. The cumulative losses of $\mathrm{NO}_{3}-\mathrm{N}$ were calculated at 11.65 and $10.56 \mathrm{~kg} \mathrm{ha}^{-1} \mathrm{NO}_{3}-\mathrm{N}$ for the $\mathrm{CT}$ and AR treatment, respectively, or a $9.4 \%$ reduction in the AR treatment during the period of study. When the season was divided based on growing season periods, the $\mathrm{NO}_{3}-\mathrm{N}$ flux values were less for the cover crop while the AR was actively growing, greater for the cover crop for the period following annual ryegrass termination through maximum crop canopy, and lower for the cover crop in the late stages of vegetative growth through relative maturity.
\end{abstract}

\section{Keywords}

Cover Crop, Annual Ryegrass, Nitrate-N, Nutrient, Best Management Practice, 


\section{Introduction}

Cover cropping utilizes the fallow period of an annual cash crop to grow a secondary crop, which can scavenge residual fertilizers [1] [2] [3], reduce erosion [4], and improve the overall health of the soil [5]. Benefits of cover crops include reduction in nutrient losses from erosion, leaching, or denitrification. Cover crops increase the infiltration of water, while the added surface residue can reduce evaporation losses, resulting in more water available to the subsequent cash crop [5] [6]. The losses of $\mathrm{NO}_{3}-\mathrm{N}$ through leaching, as $\mathrm{N}_{2}$ or $\mathrm{N}_{2} \mathrm{O}$ through denitrification, $\mathrm{NH}_{3}$ through volatilization, or as organic and ammonium nitrogen through erosion are not only economic losses in the field, but they also result in downstream consequences such as eutrophication or hypoxia [7], increase water treatment costs [8], and become heat trapping greenhouse gases [9]. Year to year $\mathrm{NO}_{3}-\mathrm{N}$ flux depends on the nitrogen use efficiency and the amount of rainfall. The highest fluxes will happen when a wet year follows a dry year with little nitrogen uptake and when nitrogen management practices remain unchanged. In order to prevent $\mathrm{NO}_{3}-\mathrm{N}$ from leaving agricultural fields, cover crops can be implemented to utilize the $\mathrm{NO}_{3}-\mathrm{N}$ remaining in the soil after harvest of the cash crop, compete with winter annual weeds, and can be used as an alternative to fall herbicides [10].

Increases in modern maize production in order to feed an ever-growing population depend on maximizing nutrient use efficiency with soil testing, improving drainage, and utilizing better hybrids. Currently, fertilizers are not always effectively managed and natural soil fertility is too commonly unaccounted. This combination leads to nutrient losses by overland flow or drainage, both natural and man-made, and their losses are becoming more of a concern [11]. The improvement in managing fertilizer and soil fertility, specifically nitrogen and phosphorus, in row crop agriculture is necessary to meet nutrient loss reduction strategies proposed in Illinois [11]. In addition, fertilizer used in an unnecessary, excessive, or untimely manner will result in either loss into the environment and/or loss in profitability [12] [13] [14]. Given the dynamic interaction among weather, agronomic practices, and soil composition, the success of reduction losses will be challenging. However, a better understanding of how these systems interact is necessary if farmers are to reduce the negative impact on the environment while being able to maintain crop production at a profitable level. We cannot afford (financially or environmentally) to simply apply "more than enough' N" [15].

Subsurface tile drainage makes modern agriculture possible in many areas of the Midwestern United States, especially much of central Illinois. According to the United States Department of Agriculture National Agricultural Statistics 
Service (USDA-NASS) census [16], there were approximately 19.65 million hectares (48.56 million acres) of drained land in the United States. Of this, 16.143 million hectares (38.89 million acres) are grain and oilseed production. Illinois has 3.41 million hectares ( 8.43 million acres) of subsurface-drained grain and oilseed land [16]. Detailed reviews presented by King et al. [17] [18] [19] summarize the necessity of tile drainage through historical expansion of arable land, increases in efficiencies by extending the time available to complete field work in the busy spring and fall seasons, maximizing productivity in the lands by stimulating mineralization, limiting denitrification and increasing nutrient availability to growing crops, minimizing crop stress from anoxic root conditions, and reducing the extent of surface erosion by allowing infiltration. However, along with its many benefits, there are inherent environmental risks associated with tile drainage. Most notably, subsurface tiles provide a shortcut from agricultural fields to nearby streams for infiltrated water. These alterations to natural soil processes pose risks to the environment due to the elevated concentrations of nutrients and pesticides in the drained water.

The Illinois Nutrient Loss Reduction Strategy (NLRS) [11] is a public-private partnership developed to address Illinois' nutrient contribution to the Gulf of Mexico, highlighting best management practices that reduce nutrient losses in Illinois, which will in turn help alleviate eutrophication in the Gulf of Mexico. The Illinois NLRS has set Phase 1 reduction milestones for $\mathrm{NO}_{3}-\mathrm{N}$ and total-P of 15 percent and 25 percent, respectively, to the Mississippi River by the year 2025 with the ultimate goal of a 45 percent reduction for both nutrients when compared to average annual riverine loading for years 1980-1996. With estimated levels of 80 percent and 48 percent of nitrate- $\mathrm{N}$ and total-P nutrient loads coming from agriculture, respectively, the reduction strategy stresses the importance of farmers' voluntary implementation of best management strategies in order to reach these goals [11]. Among the specific management practices that can be used to reach these goals are the use of cover cropping, reduction in soil tillage, delayed timing and/or decreased rates of fertilizers, or bioreactors. Cover crops can be grown in rotation with cash crops. They are seeded during the growing season or following a cash crop and can be used for many processes in nutrient cycling. Cover crops can uptake residual nutrients from previous crops and also nutrients made available during the cover crop growth period, reducing nitrate concentrations in tile flow and overall $\mathrm{N}$ load [11] [20] [21] [22] [23] [24]. Cover crops can improve the diversity of crop rotations, increase nutrients through plant fixation, decrease erosion, fracture subsoil hardpans, out-compete weeds, and reduce soil evaporation after termination [25]. However, if cover crops are interseeded during the cash crop growing season or terminated late, they can also compete with cash crops for nutrients, water, and sunlight and it is important to understand their growth cycles and manage them appropriately. Alternatively, cover crops can act as a weed if not properly managed or if weather events prevent timely termination. Cover crops, if there is inadequate rainfall, can decrease 
the available water in the subsoil [5] [26] or they can leave the ground too cool and wet to properly establish a cash crop if they are not terminated and rain continues to fall. Both scenarios may result in yield losses [27] [28] [29]. Cover crops are also an added cost to cropping practices and may not return added profits.

The objective of this study was to determine the impact of an annual ryegrass (AR) winter cover crop and tillage on $\mathrm{NO}_{3}-\mathrm{N}$ losses in tile drainage water. This study monitored the differences in daily cumulative drainage flow, water sample $\mathrm{NO}_{3}-\mathrm{N}$ concentrations, and daily $\mathrm{NO}_{3}-\mathrm{N}$ fluxes from subsurface tiles underlying the newly converted CT treatment and the continuous no-till AR winter cover crop treatment. Due to limited access and resources for this on-farm study, water samples were only collected during the maize growing season.

\section{Materials and Methods}

The research site and data collection were made possible through the conversion of a private field under normal agricultural production. Access to this field site was limited to one growing season of cover crops and maize, due to budget limitations and availability of the land and personnel. In addition, as the conventional tillage occurred in late fall when the soil temperature was quite cold (i.e. during snow cover), it is unlikely that nitrogen mineralization in the soil would have had any substantial impact on nitrogen transport before spring water quality monitoring began.

The site was located in Crawford County, IL, which met the requirements of 1) four consecutive years of no-till or minimum tillage, in which macropore drainage channels had not been compromised, 2) subsurface drainage in parallel pattern, 3) relatively level ground to maximize uniformity, 4) productive soils with drought tolerance and flood protection, and 5) previous crop harvested prior to October to allow for the proper cover crop fall establishment period.

Soil, geological and climate information were found in the Soil Survey of Crawford County, Illinois [30]. The soil in this study was Muren. This soil is part of the Central Mississippi Valley Wooded Slopes in Crawford County, Illinois. Muren is a fine silty, mixed, superactive, mesic Aquic Hapludalf having a loess parent material approximately 2.03 meters ( 80 inches) thick and forming at the summit of loess hills. It is moderately well drained and formed from deciduous hardwood forests.

Crawford County has a temperate, humid, and continental climate. It has an average temperature, as recorded in Palestine, IL, in the period 1921-2000, during the winter months of about $0^{\circ} \mathrm{C}$ and approximately $24.2^{\circ} \mathrm{C}$ during the summer months. The average annual precipitation is $109.1 \mathrm{~cm}$ (42.94 inches), of which $68.2 \mathrm{~cm}$ (26.8 inches) falls April through October during the crop growing season [30]. A parallel, subsurface drainage system with 30.5-meter (100-foot) spacing underlies the soil surface at an expected depth of between 0.76 and 1.22 meters (30 and 48 inches). 


\subsection{Tillage and Cover Crop Establishment}

All site preparation was completed with commercial farm equipment and the field study was treated as if it was a field under normal production. The site was planted with an AR cover crop with a single coulter, no-till, air seeder drill at a depth of $1.3 \mathrm{~cm}$ (0.5 inch) and a rate of $15.1 \mathrm{~kg} \mathrm{ha}^{-1}\left(13.5 \mathrm{lb} \mathrm{ac}^{-1}\right)$ on September 27,2014 . No-tillage practices were carried out on the AR treatments. A period of warm and dry weather following planting allowed the AR to quickly germinate and emerge. Planting direction was 0 degrees, North, and perpendicular with tile lines. The AR was terminated at elongation stage with herbicide on April 17, 2015.

Primary tillage was completed on the CT plots November 18, 2014 with a chisel plow fitted with straight points. The working depth was in the range of 28 $33 \mathrm{~cm}$ (11 - 13 inches). Tillage direction was 90 degrees, East, and parallel with tile lines. Herbicide was applied on April 17, 2015. Seed bed was prepared with secondary tillage by a field cultivator at a depth of approximately $10 \mathrm{~cm}$ (4 inches) just prior to planting on May 6, 2015. No tillage was performed on the AR plots.

\subsection{Cover Crop Biomass Collection}

Aboveground biomass samples were collected from each of three AR plots on April 16, 2015. The area of collection was 1175.8 square centimeters (182.3 square inches) of AR. The sampling locations were approximately 15 meters north of the southernmost drainage tile of each plot and geospatial coordinates and soil types were also recorded from each collection point. The AR biomass was dried in a forced-air oven for 24 hours at $80{ }^{\circ} \mathrm{C}$. Biomass samples were sent to Agvise Laboratories (Northwood, North Dakota, USA) for analysis of orthophosphate, total $\mathrm{P}, \mathrm{NO}_{3}-\mathrm{N}$, total $\mathrm{N}$, and total $\mathrm{C}$. Nitrogen and carbon were determined by combustion on a carbon/nitrogen analyzer (NUT.02.107). Other nutrients were determined by digesting the sample with $30 \%$ hydrogen peroxide and nitric acid with heat and then analyzing on an Inductive Coupled Plasma Spectrophotometer (ICP).

\subsection{Spring Fertilizer Application}

Calcium carbonate agricultural limestone was surface broadcast at a rate of 4.5 $\mathrm{Mg} \mathrm{ha}^{-1}\left(2\right.$ ton $\left.\mathrm{ac}^{-1}\right)$ the week of April 17, 2015. Lime was not incorporated in the cover-cropped treatment, but was incorporated in the conventional treatment during spring tillage event. All plots had liquid starter fertilizer applied with the maize planter on May 6, 2015 at a depth of $50.8 \mathrm{~mm}$ (2 in) below the surface and $50.8 \mathrm{~mm}$ laterally distanced from the rows. The liquid fertilizer was a mixture of $28 \%$ urea-ammonium-nitrate $\left(75 \mathrm{~L} \mathrm{ha}^{-1}\right)$, ammonium polyphosphate $\left(75 \mathrm{~L} \mathrm{ha}^{-1}\right)$, and ammonium thiosulfate $\left(18.7 \mathrm{~L} \mathrm{ha}^{-1}\right)$. The starter fertilizer contained $22.4 \mathrm{~kg}$ $\mathrm{N} \mathrm{ha}^{-1}\left(20 \mathrm{lbs} \mathrm{ac}^{-1}\right)$ and $16.8 \mathrm{~kg} \mathrm{ha}^{-1}\left(15 \mathrm{lbs} \mathrm{ac}^{-1}\right) \mathrm{P}_{2} \mathrm{O}_{5}$.

Plots were side-dressed with variable rates of anhydrous ammonia on June 3 , 
2015. The side dress rates were 129,155 , and $176 \mathrm{~kg} \mathrm{NH}_{3} \mathrm{ha}^{-1}$. The lower values of 129 and $155 \mathrm{~kg} \mathrm{ha}^{-1}$ represented the lower and upper range values for the maximum return to nitrogen [31]. Side dress applications were made with a 23-row single blade opener at depths of $75 \mathrm{~mm}$ (3 in).

\subsection{Maize Establishment}

Maize was planted with a double-disk no-till planter at a target population of 83,980 plants per hectare (34,000 plants per acre) with a 116-day hybrid (Dekalb $^{\circledR}$ 66-40) on May 6, 2015. Planting population was recorded with planter instrumentation and a final stand count was determined at relative maturity.

\subsection{Flow Monitoring}

The tile water flow was continuously monitored using in-line v-notch weirs and submerged pressure transducers for flow (Figure 2). Teledyne ISCO ${ }^{\circledR}$ (Lincoln, Nebraska, USA) 6712 automated water samplers were used for water collection. The upstream flow monitoring station on each line was used to measure upstream flow and grab samples were intermittently collected for $\mathrm{NO}_{3}-\mathrm{N}$ analysis. Figure 1 shows the locations of flow monitoring stations within the experimental plot.

$\mathrm{NO}_{3}-\mathrm{N}$ flux was calculated by multiplying the flow measurement by the $\mathrm{NO}_{3}-\mathrm{N}$ concentration in the water. Four in-line v-notch weirs were utilized and installed in the drainage tiles, two to measure upstream flow prior to plots 12 14 (West or left of plot 12, Figure 1) and two to measure downstream flow of plot 14 (East of plot 14, Figure 1). Any upstream contributions of flow or flux

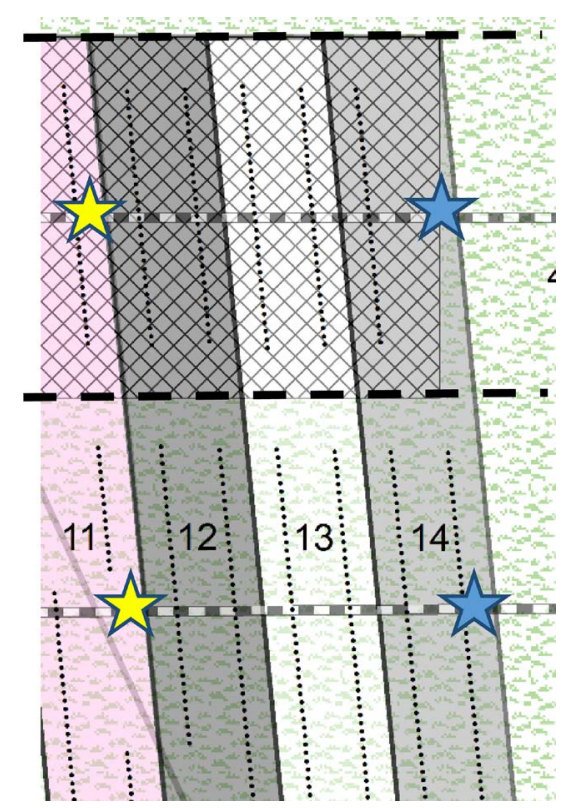

Figure 1. Specific locations of flow monitoring stations. Blue stars represent autosampler locations, yellow stars represent upstream measurement sites, hatched area represents $\mathrm{CT}$, unhatched area represents $\mathrm{AR}$, and small black dots represent yield measurements taken by the yield monitor at harvest. The plot identification numbers are also shown. 
were subtracted from downstream measurements. The drained area of the AR and CT treatments being monitored in this study were each approximately 0.17 ha $(0.41 \mathrm{ac})$.

The installations of the v-notch weir flow monitoring stations began on April 11, 2015 and ended on April 12, 2015. In order to make room for the flow monitoring stations, sections of working $10.2-\mathrm{cm}$ (4-in) tile line had to be removed. The flow monitoring sections were $15.4-\mathrm{cm}$ (6-in) diameter, non-perforated dual wall tile with a v-notch weir section (Figure 2).

The sections removed from each monitoring station contained an approximately 2-degree slope and were replaced with a section with no slope. In order to allow the upstream flow monitoring section to meet the zero slope standard, an immediate drop was sectioned where the $15.4-\mathrm{cm}$ tile coupled with the $10.2-\mathrm{cm}$ tile, leaving the tops of the tile lines flush and the $15.4-\mathrm{cm}$ section dug below grade of the $10.2-\mathrm{cm}$ tile. A laser level was used to measure the elevation of the $10.2-\mathrm{cm}$ tiles and ensure the monitoring stations were level.

Non-perforated tile was chosen for the flow monitoring section to prevent disturbed soils from entering tile lines where water was to be collected and measured. A $15.4 \mathrm{~cm}$ tile was chosen to replace a $10.2 \mathrm{~cm}$ because it allowed a v-notch weir to be built with a higher precision and range in height, while reducing the risk of backing up tile flow.

Each flow monitoring weir system was tested prior to field installation. Following testing for each unique weir, it was determined one flow curve would best represent all v-notch weirs (Equation (1)). Care was taken in installing the flow monitoring stations in the field with the same standards as they were tested in the laboratory. The flow of water in $\mathrm{L} \mathrm{s}^{-1}$ for each v-notch weir, for the purposes of the field study, was determined by the following calculation:

$$
Q_{A L L}=\left[3.007 \mathrm{e}^{-5 *} H^{3}+2.175 \mathrm{e}^{-3 *} H^{2}+2.8233^{-2} * H\right] * 0.06309
$$

where,

$Q_{A L L}=$ Flow from v notch weir (liters/second);

$H=$ water depth above the nappe of the $\mathrm{v}(\mathrm{mm})$.

Onset ${ }^{\circledR}$ (Bourne, MA, USA) HOBO ${ }^{\circledR}$ U20L-04 pressure transducers were used to determine the water depth $(H)$ in the tile lines. These pressure transducers measure absolute pressure with an accuracy of $0.1 \%$ full scale or $4 \mathrm{~mm}$, but in order to do this, they must have another pressure transducer reading for barometric

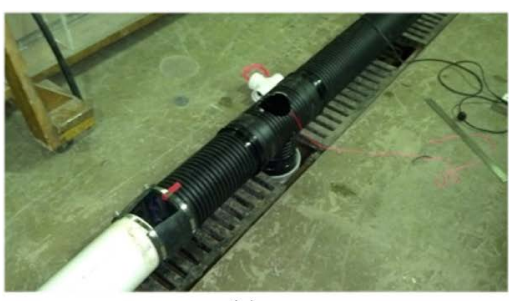

(a)

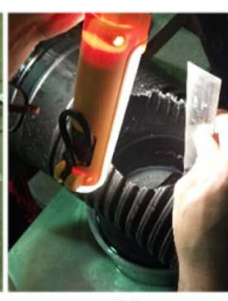

(b)

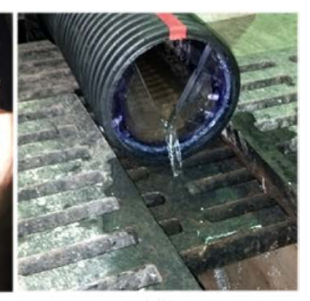

(c)

Figure 2. (a) Laboratory setup for testing; (b) water depth; and (c) flow with a v-notch weir. 
compensation. This study had four flow monitoring stations which required four pressure transducers, and a fifth pressure transducer for barometric compensation. The fifth pressure transducer was placed approximately 2 feet $(61 \mathrm{~cm})$ below the surface and above the flowing water in the riser of the downstream AR monitoring station. Placing the fifth pressure transducer below surface kept it at a more constant temperature relative to the submerged pressure transducers. All other pressure transducers were placed at the bottom of the flow basins, or at a depth of approximately $21.5 \mathrm{~cm}$ below the nappe of the " $\mathrm{v}$ " of the v-notch weir. The pressure transducers recorded absolute pressure and temperature at 15-minute intervals throughout the study and collected nearly 44,400 flow values from April 12, 2015 through July 21, 2015, which was the last day of tile flow for this study period. Pressure transducer data were stored internally, but were routinely downloaded using HOBOware ${ }^{\circledR}$ Pro $^{\mathrm{TM}}$ software in which the data were processed from absolute pressure, to water depth for each individual, submerged pressure transducer.

Collected samples retrieved from the autosamplers were immediately placed on ice during transport and then refrigerated at the Agricultural Engineering Sciences Building at the University of Illinois Urbana-Champaign. Samples were either analyzed upon collection or frozen and thawed later for analysis. Autosamplers were programmed to collect a sample every 4 hours starting at 12:00 am each day, giving approximately $150 \mathrm{~mL}$ "sips" at 00:00, 04:00, 08:00, 12:00, 16:00, and 20:00 in each bottle. Autosamplers were programmed to take sips that were composited versus one large daily sample in order to collect water at different stages of flow.

\subsection{Flow Analysis}

The flow of water in the subsurface tiles was analyzed for the entire season and then segregated into three periods: prior to cover crop termination (April 12-April 18, 2015); cover crop termination to full crop canopy (April 19-June 18, 2015), and full crop canopy to study end (June 19-September 28, 2015). It should be noted that the study ended September 28. However, tile flow ended on July 21. For the AR and CT treatments, nitrate/nitrite- $\mathrm{N}$ (referred to as $\mathrm{NO}_{3}-\mathrm{N}$ in this study) water sample analysis was completed for $53.5 \%$ and $55.1 \%$ of total flow, respectively. The majority of the water left unanalyzed was from the month of April in which all samples collected showed little variability in nutrient concentrations regardless of flow.

\subsection{Nutrient Analysis}

Nutrient analysis was conducted at the Water Quality Laboratory in the Department of Agricultural and Biological Engineering at the University of Illinois Urbana-Champaign. Samples were analyzed for $\mathrm{NO}_{3}-\mathrm{N}$ using the Automated Hydrazine Reduction Method (Standards Methods $4500-\mathrm{NO}_{3}-\mathrm{H}, \mathrm{NEMI}$ ). Spiked samples, duplicate samples, and standard solutions were incorporated into nu- 
trient analyses for quality control.

\subsection{Maize Biomass Samples}

On September 20, 2015, at approximate relative maturity for maize, harvestable stand count was recorded and select above ground portions of plants were collected and weighed. The stand count was done by measuring a length of $5.31 \mathrm{~m}$ (17 ft 5 in) and counting plants with a harvestable ear on rows 6, 5, and 4 of each treatment. Following a stand count, the $6^{\text {th }}, 16^{\text {th }}$, and $26^{\text {th }}$ plants were cut off at ground level and collected for analysis. All samples had a fresh weight recorded and they were then stored at $4{ }^{\circ} \mathrm{C}$ until they could be chopped and dried. Plant samples were run through a tree chipper prior to drying. Samples were dried using a forced air oven at $60^{\circ} \mathrm{C}$ for 7 days. They were then weighed again and chopped into $5 \mathrm{~mm}$ pieces using a knife mill in preparation for shipping and analysis. They were sent to Agvise Laboratories (Northwood, ND) for analysis for total $\mathrm{P}$, total $\mathrm{N}$, and total $\mathrm{C}$.

\subsection{Yield Measurement}

The focus on yield analysis was to use the mass flow sensor and internal software in a John Deere ${ }^{\mathrm{TM}}$ combine to determine yield. This method creates a much larger yield dataset than would otherwise be possible using a weigh wagon for each plot or hand harvesting. Harvest was completed on September 28, 2015 at a constant speed of $4.7 \mathrm{~km} \mathrm{hr}^{-1}(2.9 \mathrm{mph})$ despite treatment harvest appearance or yield monitor readings. Each 24-row treatment was harvested by two, 12-row passes $(9.14 \mathrm{~m})$. Yield monitors in the combine collect data at a 1-second interval, or every 1.3 meters, which creates a harvest area of $11.85 \mathrm{~m}^{2}\left(127.6 \mathrm{ft}^{2}\right)$ for each point collected.

\subsection{Statistical Analysis}

Differences between the AR and CT treatments were analyzed for significance using an F Test Two Samples for Variances to determine if the variances were equal, followed by either a Two Sample $t$ Test for unequal variances or Two Sample $t$ Test for equal variance, depending on the result of the F test (Microsoft Excel).

\section{Results and Discussion}

The results from this study are presented for the entire study period first, followed by closer looks at strategic periods within the study period. These strategic periods were prior to cover crop termination (April 12-April 18, 2015), cover crop termination to full crop canopy (April 19-June 18, 2015), and full crop canopy to study end (June 19-September 28, 2015). It should be noted that the study ended September 28. However, tile flow ended on July 21. The $p$-values are used for comparison of the AR and CT treatments. Due to variability in flow throughout the study period (Table 2), the $p$-values often show no significant difference between treatments $(p>0.05)$. However, the numerical differences are 
still examined and discussed.

\subsection{Study Weather Conditions}

This study spanned from September 27, 2014, when the AR cover crop was planted, through September 28, 2015, when the maize was harvested. Since this study spanned only one cover crop and maize growing season, the observed temperature and precipitation data are presented in Table 1, along with historical data for comparison. The weather conditions, in terms of temperature and precipitation, were well suited for high maize yields during this time. Following termination of the winter cover crop in mid-April, there was a period of warm and dry weather, which allowed planting and an even germination and emergence of maize plants. The growing season for the maize crop from emergence to maturity brought above normal rainfall patterns during the months of March, April, and June and slightly below average rainfall during the months of July and August. The rainfall events were frequent which minimized plant water stress.

\subsection{Full Season Analysis}

Water flowed through tile lines intermittently due to rain events from the date of installation on April 12, 2015 through the July 21, 2015. During this period, approximately 402,517 liters and 320,393 liters drained through the AR and CT

Table 1. Comparing the observed monthly average temperature and precipitation to average historical values (1971-2000 in Palestine, IL) [30].

\begin{tabular}{|c|c|c|c|c|c|c|}
\hline \multicolumn{7}{|c|}{ Weather Observations vs. Historical Averages } \\
\hline \multirow{2}{*}{$\begin{array}{c}\text { Date } \\
\text { Month }\end{array}$} & \multicolumn{4}{|c|}{ Temperature } & \multicolumn{2}{|c|}{ Precipitation } \\
\hline & $\begin{array}{l}\text { Observed } \\
\text { Avg Low } \\
{ }^{\circ} \mathrm{C}\end{array}$ & $\begin{array}{l}\text { Historical } \\
\text { Avg Low } \\
{ }^{\circ} \mathrm{C}\end{array}$ & $\begin{array}{c}\text { Observed } \\
\text { Avg High } \\
{ }^{\circ} \mathrm{C}\end{array}$ & $\begin{array}{l}\text { Historical } \\
\text { Avg High } \\
{ }^{\circ} \mathrm{C}\end{array}$ & $\begin{array}{c}\text { Observed } \\
\mathrm{cm}\end{array}$ & $\begin{array}{c}\text { Historical } \\
\text { Avg } \\
\mathrm{cm}\end{array}$ \\
\hline Sept. 2014 & 11.4 & 12.9 & 25.7 & 26.7 & 13.1 & 8.9 \\
\hline Oct. 2014 & 7.8 & 7.3 & 19.8 & 20.3 & 10.5 & 7.5 \\
\hline Nov. 2014 & -2.7 & 2.3 & 7.7 & 12.3 & 4.3 & 9.9 \\
\hline Dec. 2014 & -1.6 & -3.3 & 4.7 & 5.4 & 7.3 & 8.0 \\
\hline Jan. 2015 & -6.5 & -6.3 & 2.9 & 2.9 & 2.7 & 6.5 \\
\hline Feb. 2015 & -12.5 & -3.6 & -0.5 & 6.1 & 4.5 & 6.8 \\
\hline Mar. 2015 & -1.6 & 1.7 & 9.5 & 12.5 & 11.9 & 9.7 \\
\hline Apr. 2015 & 6.6 & 6.8 & 18.7 & 18.8 & 13.7 & 10.1 \\
\hline May 2015 & 13.7 & 12.2 & 25.1 & 24.6 & 8.5 & 11.9 \\
\hline June 2015 & 18.1 & 17.0 & 27.7 & 29.4 & 15.6 & 9.7 \\
\hline July 2015 & 18.6 & 19.1 & 28.9 & 31.2 & 8.7 & 10.6 \\
\hline Aug. 2015 & 15.3 & 18.3 & 28.4 & 30.2 & 8.6 & 9.7 \\
\hline Sept. 2015 & 13 & 12.9 & 27.9 & 26.7 & 9.8 & 8.9 \\
\hline
\end{tabular}


treatments, respectively.

Subsurface drainage continued for a large portion of the growing season, with the final period of flow happening on July 21 . This was largely a combination of adequate rainfall and the size of the events, which provided excess soil water. Most daily rainfall events that triggered large flows were greater than $3.8 \mathrm{~cm}(1.5$ in). During much of the growing season, flow ceased in the CT plot prior to the AR plot. It was not until mid-June that the flow patterns were more uniform and equal between the two treatments. Figure 3 displays the cumulative flow comparison with the gray dashed line representing the AR treatment and the black line representing CT treatment.

The seasonal comparison, which spanned April 12-September 28, 2015, of daily flow means (Table 2) highlights that the mean daily flow values were greater for AR than CT. This signifies either the AR treatment maintained a greater amount of water in the soil profile through reduced evaporation, or the
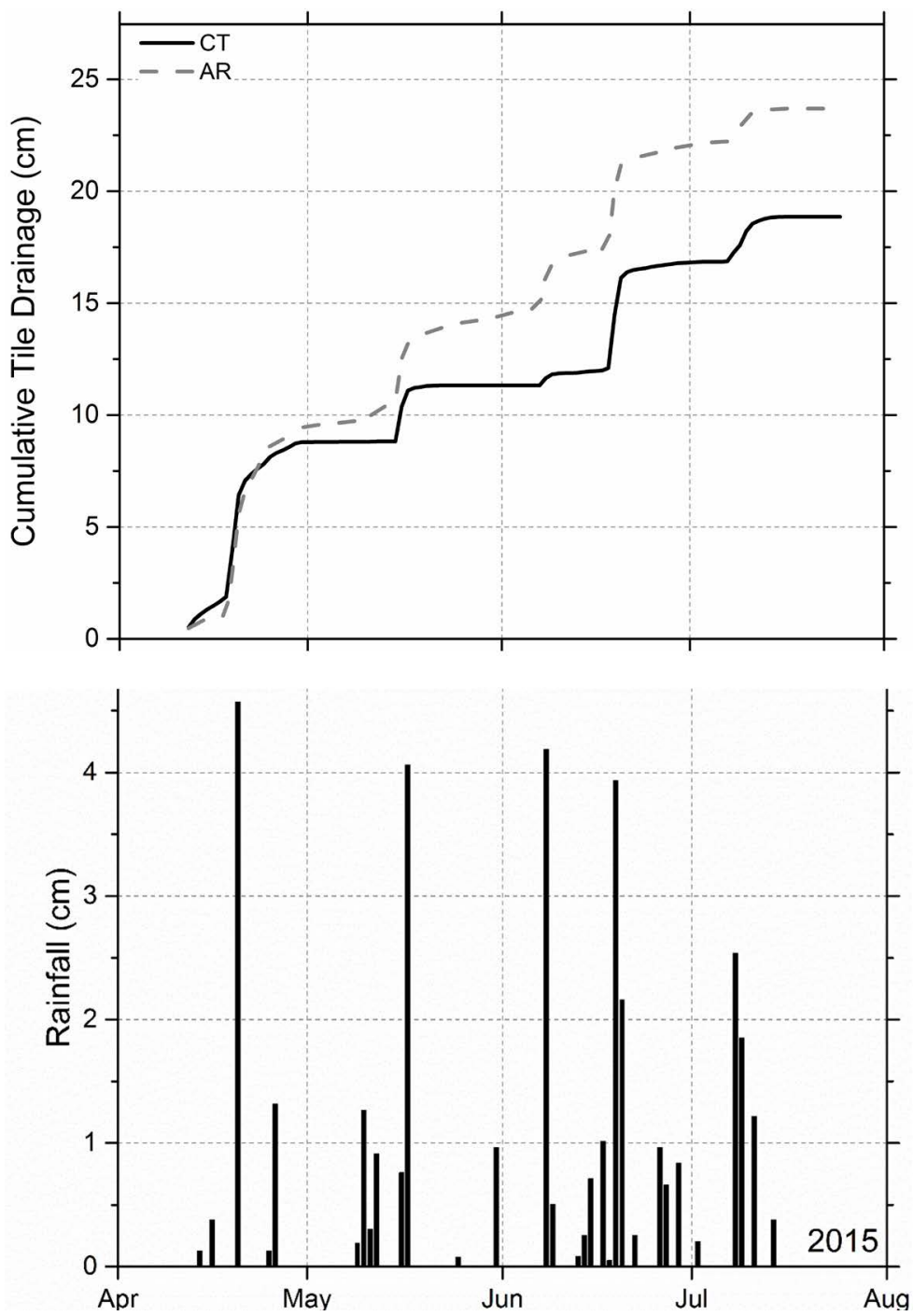

Figure 3. Cumulative tile drainage and site daily rainfall for 2015 growing season comparing conventional tillage (CT) to annual ryegrass (AR). 
Table 2. Daily $\mathrm{NO}_{3}-\mathrm{N}$ concentrations, flow, and flux from annual ryegrass (AR) and conventional tillage (CT) flow monitoring stations from entire season. The number of samples (N), as well as the mean, standard error (SE), and standard deviation are also provided. The $p$-values were calculated using an F Test Two Samples for Variances followed by either a Two Sample $t$ Test for unequal variances or Two Sample $t$ Test for equal variance, depending on the result of the $\mathrm{F}$ test, to evaluate significant differences between the AR and CT treatments.

\begin{tabular}{|c|c|c|c|c|c|}
\hline \multicolumn{6}{|c|}{ Descriptive Statistics $\left[\mathrm{NO}_{3}-\mathrm{N}\right.$ Flux $]$} \\
\hline & $\mathrm{N}$ & Mean & SE Mean & Standard Deviation & $p$-value \\
\hline $\mathrm{AR} \mathrm{NO}_{3}-\mathrm{N}\left[\mathrm{mg} \mathrm{L}^{-1}\right]$ & 44 & 3.77 & 0.21 & 1.39 & \multirow{2}{*}{$3.98 \mathrm{E}-07$} \\
\hline 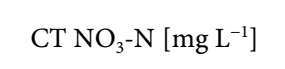 & 50 & 5.31 & 0.19 & 1.34 & \\
\hline AR Daily Flow $[L]$ & 111 & 3626.28 & 728.92 & 7679.63 & \multirow{2}{*}{0.466} \\
\hline CT Daily Flow $[\mathrm{L}]$ & 111 & 2886.42 & 703.24 & 7409.10 & \\
\hline AR Daily Flux $\left[\mathrm{kg} \mathrm{ha}^{-1}\right]$ & 44 & 0.158 & 0.056 & 0.368 & \multirow{2}{*}{0.984} \\
\hline CT Daily Flux $\left[\mathrm{kg} \mathrm{ha}^{-1}\right]$ & 50 & 0.157 & 0.061 & 0.431 & \\
\hline
\end{tabular}

undisturbed macropore flow paths allowed a less resistant path towards the drainage tile. Subsurface water analyzed for $\mathrm{NO}_{3}-\mathrm{N}$ concentrations was generally greater for the $\mathrm{CT}$ treatment. The mean $\mathrm{NO}_{3}-\mathrm{N}$ concentration of the $\mathrm{CT}$ treatment was $5.31 \mathrm{mg} \mathrm{L}^{-1} \mathrm{NO}_{3}-\mathrm{N}$, while the mean concentration for the AR treatment was $3.77 \mathrm{mg} \mathrm{L}^{-1} \mathrm{NO}_{3}-\mathrm{N}$. This is likely a combination of two factors: 1) CT resulted in greater soil mineralization from exposing soil organic matter to microbial breakdown, and 2) the AR treatment had greater water flow, which acted as a source of dilution.

The numerical values for daily $\mathrm{NO}_{3}-\mathrm{N}$ flux are expressed in Table 4. Greater flow from the AR treatment impacted the $\mathrm{NO}_{3}-\mathrm{N}$ flux comparison. Since flow was greater from the AR treatment for a majority of the season, the lower $\mathrm{NO}_{3}-\mathrm{N}$ concentrations were offset by this larger volume of flow. Most daily $\mathrm{NO}_{3}-\mathrm{N}$ flux values were greater for the AR treatment than the $\mathrm{CT}$ treatment due to longer flow durations and a greater total flow volume. However, $\mathrm{NO}_{3}-\mathrm{N}$ lost during rain events was large enough from the CT to offset the difference and result in greater cumulative $\mathrm{NO}_{3}-\mathrm{N}$ losses (flux).

The full season analysis of subsurface tile water provides a seasonal comparison of the CT treatment versus the no-tillage AR treatment (Figure 4). Utilizing analyzed and extrapolated water sample concentrations from linear interpolation, a cumulative $\mathrm{NO}_{3}-\mathrm{N}$ flux curve was developed. The CT treatment had two periods in which the $\mathrm{NO}_{3}-\mathrm{N}$ flux was greater than the AR treatment, the beginning of the season in which the cover crop was growing and also the period in which the maize crop was at maximum canopy. Despite the AR treatment having a $29 \%$ lower daily $\mathrm{NO}_{3}-\mathrm{N}$ concentration $(p=3.976 \mathrm{E}-07)$, there was no significant difference in daily flow $(p=0.466)$ or daily $\mathrm{NO}_{3}-\mathrm{N}$ flux $(p=0.984)$ between AR and CT for this study period of April-July 2015. The cumulative losses of $\mathrm{NO}_{3}-\mathrm{N}$, including interpolated values for missing samples, were calculated at 


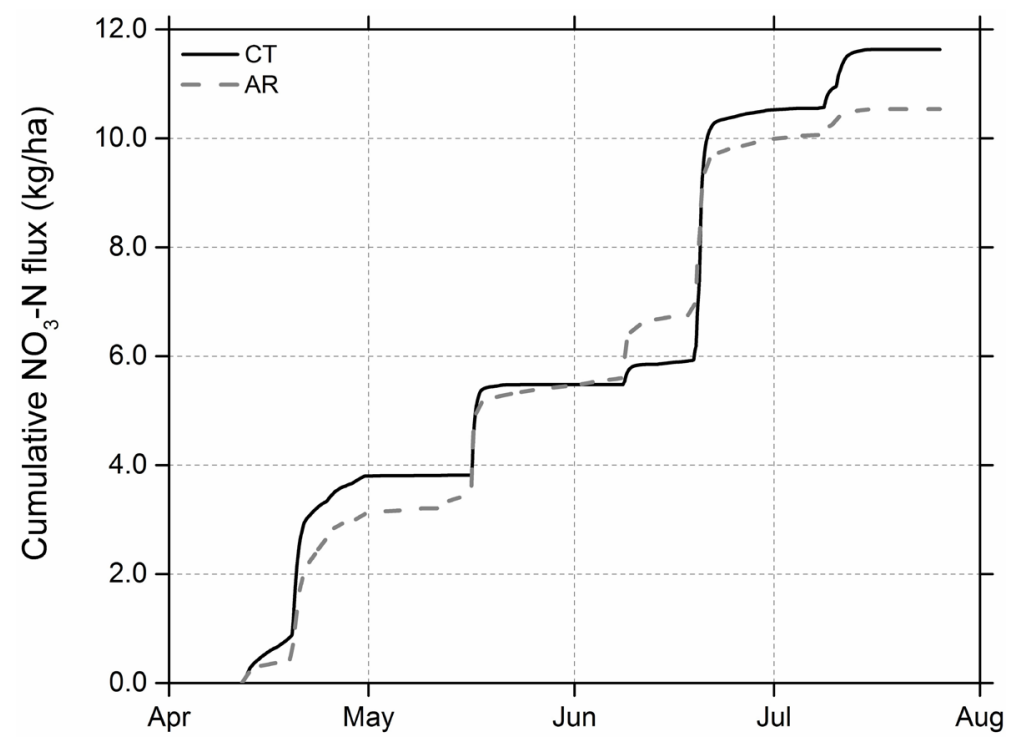

Figure 4. Comparing growing season cumulative $\mathrm{NO}_{3}-\mathrm{N}$ flux for conventional tillage (CT) to annual ryegrass (AR).

11.65 and $10.56 \mathrm{~kg} \mathrm{ha}^{-1} \mathrm{NO}_{3}-\mathrm{N}$ for the $\mathrm{CT}$ and $\mathrm{AR}$ treatments, respectively, with the AR treatment decreasing losses by $9.4 \%$ in terms of cumulative $\mathrm{NO}_{3}-\mathrm{N}$ flux during the period of study. This trend of a winter cover crop reducing $\mathrm{NO}_{3}-\mathrm{N}$ losses in tile drainage when combined with spring nitrogen application is in agreement with the 13\% reduction observed by Strock et al. (2004) [18], however, is much less than the $40 \%$ observed by Ruffatti et al. (2019) [14].

\subsection{Living Cover Crop}

The $\mathrm{NO}_{3}-\mathrm{N}$ concentrations, flow, and flux measurements were collected and analyzed to look specifically at the period of cover crop growth, April 12-April 18, 2015 (Table 3). This period marks the portion of the growing season in

Table 3. Daily $\mathrm{NO}_{3}-\mathrm{N}$ concentrations, flow, and flux from annual ryegrass (AR) and conventional tillage (CT) flow monitoring stations for April 12-18, 2015. The number of samples $(\mathrm{N})$, as well as the mean, standard error (SE), and standard deviation are also provided. The $p$-values were calculated using an F Test Two Samples for Variances followed by either a Two Sample $t$ Test for unequal variances or Two Sample $t$ Test for equal variance, depending on the result of the $\mathrm{F}$ test, to evaluate significant differences between the AR and CT treatments.

\begin{tabular}{cccccc}
\hline \multicolumn{7}{c}{ Descriptive Statistics $\left[\mathrm{NO}_{3}\right.$-N Flux $]$} & \\
\hline & $\mathrm{N}$ & Mean & SE Mean & Standard Deviation & $p$-value \\
\hline $\mathrm{AR} \mathrm{NO}_{3}$-N $\left[\mathrm{mg} \mathrm{L}^{-1}\right]$ & 2 & 3.55 & 0.368 & 0.52 & 0.303 \\
$\mathrm{CT} \mathrm{NO}_{3}$-N $\left[\mathrm{mg} \mathrm{L}^{-1}\right]$ & 2 & 4.27 & 0.017 & 0.024 & \\
AR Daily Flow [L] & 7 & 2635.27 & 955.63 & 2528.37 & 0.150 \\
CT Daily Flow [L] & 7 & 4569.57 & 819.66 & 2168.62 & \\
AR Daily Flux [kg ha & \\
CT Daily Flux $\left[\mathrm{kg} \mathrm{ha}^{-1}\right]$ & 2 & 0.105 & 0.083 & 0.118 & 0.713 \\
\hline
\end{tabular}


which the tile flow was measured while the cover crop was still living.

The $\mathrm{NO}_{3}-\mathrm{N}$ concentrations, flow, and daily flux values were numerically less for the AR treatment than the CT treatment during the period when the winter cover crop was actively growing. However, there was no statistically significant difference between the AR and CT treatments for the April 12-18 period. The variability in daily flow is likely the reason for the higher $p$-values $(>0.05)$. Therefore, it is still valuable to discuss the numerical differences. The AR treatment influenced a $16.9 \%$ reduction in daily $\mathrm{NO}_{3}-\mathrm{N}$ concentrations from tile water samples, a $42.3 \%$ reduction in daily flow, and $30.5 \%$ reduction in daily $\mathrm{NO}_{3}-\mathrm{N}$ flux. An actively growing grass crop may have reduced the $\mathrm{NO}_{3}-\mathrm{N}$ flux in two ways: 1) uptake of available nitrogen from the soil profile thereby reducing $\mathrm{NO}_{3}-\mathrm{N}$ leaching losses, and 2) the uptake of soil water and a greater net transpiration resulting in less tile water flow. In addition, there was likely an increase in soil mineralization in the CT plots. Even with a late tillage event and a cooler than average spring, subsurface $\mathrm{NO}_{3}-\mathrm{N}$ values were still elevated in the CT plot. It is known that high levels of nutrients can be lost during winter months when the soil is not frozen and tile drainage runoff is occurring [32] [33]. Therefore, this first sampling period provides some insight into the difference in treatments prior to maize planting.

\subsection{Early Vegetative Maize Growth Following Cover Crop Termination}

Daily $\mathrm{NO}_{3}-\mathrm{N}$ concentrations flow, and flux measurements were collected and analyzed for the period which immediately followed cover crop termination up to point of assumed evapotranspiration equilibrium (full crop canopy of both treatments). This period was April 19-June 18, 2015 (Table 4).

There were no statistically significant differences $(p>0.05)$ between the AR

Table 4. Daily $\mathrm{NO}_{3}-\mathrm{N}$ concentrations, flow, and flux from annual ryegrass (AR) and conventional tillage (CT) flow monitoring stations for April 19-June 18, 2015. The number of samples $(\mathrm{N})$, as well as the mean, standard error (SE), and standard deviation are also provided. The $p$-values were calculated using an F Test Two Samples for Variances followed by either a Two Sample $t$ Test for unequal variances or Two Sample $t$ Test for equal variance, depending on the result of the $\mathrm{F}$ test, to evaluate significant differences between the AR and CT treatments.

\begin{tabular}{|c|c|c|c|c|c|}
\hline \multicolumn{6}{|c|}{ Descriptive Statistics $\left[\mathrm{NO}_{3}-\mathrm{N}\right.$ Flux] } \\
\hline & $\mathrm{N}$ & Mean & SE Mean & Standard Deviation & $p$-value \\
\hline $\mathrm{AR} \mathrm{NO}_{3}-\mathrm{N}\left[\mathrm{mg} \mathrm{L}^{-1}\right]$ & 25 & 3.28 & 0.21 & 1.04 & \multirow{2}{*}{$1.18 \mathrm{E}-08$} \\
\hline $\mathrm{CT} \mathrm{NO}_{3}-\mathrm{N}\left[\mathrm{mg} \mathrm{L}^{-1}\right]$ & 30 & 5.06 & 0.17 & 0.93 & \\
\hline AR Daily Flow $[L]$ & 61 & 4605.98 & 1088.57 & 8502.00 & \multirow{2}{*}{0.235} \\
\hline CT Daily Flow [L] & 61 & 2844.35 & 994.94 & 7770.75 & \\
\hline AR Daily Flux [ $\left.\mathrm{kg} \mathrm{ha}^{-1}\right]$ & 25 & 0.129 & 0.061 & 0.304 & \multirow{2}{*}{0.441} \\
\hline CT Daily Flux $\left[\mathrm{kg} \mathrm{ha}^{-1}\right]$ & 30 & 0.073 & 0.038 & 0.206 & \\
\hline
\end{tabular}


and CT treatments for the daily flow or daily $\mathrm{NO}_{3}-\mathrm{N}$ flux for the April 19-June 18 period. The daily flow values continued to be quite variable. The cumulative $\mathrm{NO}_{3}-\mathrm{N}$ fluxes following cover crop termination were $76.7 \%$ greater for the AR treatment than the CT treatment. This was likely due to the greater flow from the AR treatment. The AR treatment likely provided a less resistant flow path for water and nutrients to the subsurface drainage tiles by way of root channels created by the ryegrass and undisturbed macropore channels. During this period, there were also likely greater evaporative losses from the CT plot due to reduced residue cover following a fallow winter.

The AR treatment had a $35.2 \%$ lower mean daily $\mathrm{NO}_{3}-\mathrm{N}$ concentration $(p=$ $1.18 \mathrm{E}-08$ ) than the $\mathrm{CT}$ treatment during the period immediately following cover crop termination to full canopy of the following maize crop. Larger $\mathrm{NO}_{3}-\mathrm{N}$ concentrations from the CT treatment are likely due to a combination of stimulated mineralization caused by conventional tillage and the lower flow rates observed for this period of study. The lower $\mathrm{NO}_{3}-\mathrm{N}$ values from the AR treatment were likely a combination of greater dilution from more water storage in the soil and also the immobilizing effect annual ryegrass residue breakdown would have had on available soil nitrogen.

\subsection{Late Vegetative and Reproductive Growth}

The late season vegetative and reproductive growth period was June 19-September 30, 2015.

The daily flow measurements for the AR and CT treatments for late vegetative period through the end of the season are given in Table 5. The AR no longer reduced evaporation from the soil surface and the depth of the corn roots likely equalized the deeper infiltration of the two treatments. The result is the treatments

Table 5. Daily $\mathrm{NO}_{3}-\mathrm{N}$ concentrations, flow, and flux from annual ryegrass (AR) and conventional tillage (CT) flow monitoring stations for June 19-September 30, 2015. The number of samples (N), as well as the mean, standard error (SE), and standard deviation are also provided. The $p$-values were calculated using an F Test Two Samples for Variances followed by either a Two Sample $t$ Test for unequal variances or Two Sample $t$ Test for equal variance, depending on the result of the $\mathrm{F}$ test, to evaluate significant differences between the AR and CT treatments.

\begin{tabular}{cccccc}
\hline \multicolumn{5}{c}{ Descriptive Statistics $\left[\mathrm{NO}_{3}\right.$-N Flux $]$} & \\
\hline & $\mathrm{N}$ & Mean & SE Mean & Standard Deviation & $p$-value \\
\hline $\mathrm{AR} \mathrm{NO}_{3}-\mathrm{N}\left[\mathrm{mg} \mathrm{L}^{-1}\right]$ & 17 & 4.50 & 0.39 & 1.62 & \\
$\mathrm{CT} \mathrm{NO}_{3}-\mathrm{N}\left[\mathrm{mg} \mathrm{L}^{-1}\right]$ & 18 & 5.82 & 0.42 & 1.78 & 0.029 \\
AR Daily Flow [L] & 43 & 2397.80 & 1047.52 & 6869.05 & \multirow{2}{*}{0.860} \\
CT Daily Flow [L] & 43 & 2672.11 & 1144.40 & 7504.30 & \\
AR Daily Flux $\left[\mathrm{kg} \mathrm{ha}^{-1}\right]$ & 17 & 0.209 & 0.114 & 0.469 & 0.652 \\
CT Daily Flux $\left[\mathrm{kg} \mathrm{ha}^{-1}\right]$ & 18 & 0.297 & 0.154 & 0.654 & \\
\hline
\end{tabular}


drainages are at more of an equilibrium than they were at any other time in the season analysis.

The analysis of the late vegetative and early reproductive stages, from June 19-July 21, 2015, of the maize crop represented a period in which soil evaporation values were assumed to have negligible differences between the two treatments. The maize of both treatments had grown to a stage that, by visual confirmation, would have provided equal shading of the soil surface and a more similar evapotranspiration coefficient.

In the late stages of the season, the CT treatment had a $29.3 \%$ higher ( $p=$ $0.029)$ mean daily $\mathrm{NO}_{3}-\mathrm{N}$ concentration and a $42.1 \%$ higher $(p=0.652)$ daily $\mathrm{NO}_{3}-\mathrm{N}$ flux than the AR treatment. Additional nitrogen from mineralization that is caused by tillage in combination with the immobilization of nitrogen during breakdown of annual ryegrass residues are the most likely contributors to larger $\mathrm{NO}_{3}-\mathrm{N}$ concentrations in the $\mathrm{CT}$ treatment. It is likely that $\mathrm{NO}_{3}-\mathrm{N}$ had slowly been leaching down the profile from tillage practices in the early spring, and the $\mathrm{NO}_{3}-\mathrm{N}$ lost later in the season was from early season losses below the root zone. This period also marked the highest concentrations of $\mathrm{NO}_{3}-\mathrm{N}$, likely as a result of soil warming and mineralization, nitrogen fertilizer applications, and adequate rainfall to move nitrogen from the surface layers of soil to the subsurface layer where the drainage tile rests.

Although the mean $\mathrm{NO}_{3}-\mathrm{N}$ concentrations were greater for the CT treatment, the last samples collected for the study were of values 3.72 and $2.88 \mathrm{mg} \mathrm{L}^{-1}$ $\mathrm{NO}_{3}-\mathrm{N}$ for the annual ryegrass and CT treatment, respectively. Not only had the concentrations fallen back to more equal levels for the two treatments, but the CT treatment had a lower concentration than the AR treatment and marked one of only three days throughout the study in which a lower nitrate concentration was obtained from the CT treatment. The other two occurrences were on the second to last day of water collection, and a rainfall measuring greater than 2.54 $\mathrm{cm}$ followed starter fertilization and cover crop termination.

\subsection{Cover Crop Biomass Analysis}

The cover crops in this study were used as a resource to scavenge available soil nitrogen and, in turn, reduce leaching and denitrification losses. Table 6 shows certain characteristics of the growing cover crop prior to termination and the expected plant available nitrogen (PAN) to be released to the maize crop.

Table 6. Annual ryegrass nutrient uptake.

\begin{tabular}{cccccccc}
\hline \multicolumn{7}{c}{ Annual Ryegrass } \\
\hline Plot ID & Soil & $\begin{array}{c}\text { Above Ground Biomass } \\
\mathrm{kg} \mathrm{ha}^{-1}\end{array}$ & C:N ratio & $\begin{array}{c}\text { Total-N } \\
\mathrm{kg} \mathrm{ha}^{-1}\end{array}$ & $\begin{array}{c}\text { Total-P } \\
\mathrm{kg} \mathrm{ha}^{-1}\end{array}$ & $\begin{array}{c}\text { Total-N } \\
\%\end{array}$ & $\begin{array}{c}\text { PAN }^{*} \\
\mathrm{~kg} \mathrm{ha}^{-1}\end{array}$ \\
\hline 12 & $453 \mathrm{~A}$ & 846 & 19.7 & 18.4 & 3.0 & 2.17 & 4.7 \\
13 & $453 \mathrm{~A}$ & 923 & 19.7 & 20.0 & 3.2 & 2.17 & 5.1 \\
14 & 453A & 930 & 19.7 & 20.2 & 3.3 & 2.17 & 5.2 \\
\hline
\end{tabular}


An important characteristic of plant material is the carbon to nitrogen ratio. A commonly accepted value of less than 20 is expected to mineralize nitrogen. The AR was slightly less than the 20 ratio, thus it would be expected to mineralize nitrogen. Most of the nitrogen that was absorbed by the actively growing cover crop is not considered PAN, and the amount of nitrogen considered PAN is minimal. However, small amounts of fertilizer nitrogen appear to have had measurable impacts on final yields.

\subsection{Maize Biomass Analysis and Yield}

The analysis performed on the aboveground portion of maize shows the potential variability of a hybrid when the growing conditions are varied by tillage and soil nitrogen fertility (Table 7).

Table 7. Nutrient uptake of maize crop at relative maturity.

\begin{tabular}{ccccccc}
\hline Plot No. & 13 & 14 & 12 & 13 & 14 & 12 \\
Soil & Muren & Muren & Muren & Muren & Muren & Muren \\
Treatment & CT & CT & CT & AR & AR & AR \\
NH Timing $_{\text {N }}$ & Side & Side & Side & Side & Side & Side \\
N Rate $\left(\mathrm{kg} \mathrm{ha}^{-1}\right)$ & 151.00 & 177.00 & 198.00 & 151.00 & 177.00 & 198.00 \\
Biomass $\left(\mathrm{g} \mathrm{plant}^{-1}\right)$ & 299.10 & 322.10 & 364.90 & 240.70 & 280.40 & 264.60 \\
Harvest Stand $\left(\mathrm{plant} \mathrm{ha}^{-1}\right)$ & 81546.00 & 75780.00 & 83194.00 & 78252.00 & 79899.00 & 79899.00 \\
Biomass $\left(\mathrm{Mg} \mathrm{ha}^{-1}\right)$ & 24.39 & 24.41 & 30.36 & 18.84 & 22.41 & 21.14 \\
Yield $\left(\mathrm{kg} \mathrm{ha}^{-1}\right)$ & 16026.00 & 16653.00 & 16842.00 & 13703.00 & 14444.00 & 15379.00 \\
Biomass-N $\left(\mathrm{kg} \mathrm{ha}^{-1}\right)$ & 219.50 & 219.70 & 425.00 & 131.90 & 201.70 & 190.30 \\
\hline
\end{tabular}

For the CT treatment, plant uptake of nitrogen exceeded the fertilizer application rate of nitrogen on each plot. These results are consistent with the elevated leaching losses observed in the drainage water analysis, which is likely due to increased mineralization in the conventionally tilled soil. The biomass- $\mathrm{N}$ value for the sample from Plot 12 (CT) of $425 \mathrm{~kg} \mathrm{ha}^{-1}$ is much greater than the applied amount. This higher uptake is likely due to greater $\mathrm{N}$ supply and uptake from soil mineralization. The lower leaves in the other test plots had more visible senescence whereas there was very little observed in the high nitrogen rate conventional plot, likely a response of remobilizing nutrients to support grain fill. CT treatments also resulted in a greater plant biomass when compared to AR treatments. The highest yield of $16,842 \mathrm{~kg} \mathrm{ha}^{-1}$ accumulated $425 \mathrm{~kg} \mathrm{ha}^{-1}$ of nitrogen. However, a yield of $16,653 \mathrm{~kg} \mathrm{ha}^{-1}$ was observed with a nitrogen value of 219.7 $\mathrm{kg} \mathrm{ha}^{-1}$ and is a reminder of the variability in nutrient uptake and ability of modern hybrids to repartition limited nutrients and still achieve high yield levels.

\section{Conclusion}

Excess rainfall created tile flow through mid-July. The cumulative values of $\mathrm{NO}_{3}-\mathrm{N}$ flux and average $\mathrm{NO}_{3}-\mathrm{N}$ concentrations were greater for the CT treatment. When 
comparing the total tile drainage flow, the AR treatment had a greater cumulative flow than the $\mathrm{CT}$ treatment. When the season was divided based on growing season periods, the $\mathrm{NO}_{3}-\mathrm{N}$ flux values were less for the cover crop while the AR was actively growing, greater for the cover crop for the period following annual ryegrass termination through maximum crop canopy, and lower for the cover crop in the late stages of vegetative growth through relative maturity. $\mathrm{NO}_{3}-\mathrm{N}$ concentrations were greater for the CT treatment than the AR treatment until the final two dates of water analysis. While the AR cumulative $\mathrm{NO}_{3}-\mathrm{N}$ flux was lower than that from the $\mathrm{CT}$ treatment, maize yields were also lower from the AR treatment. This may signify that nitrogen was either tied up in forms not available to the maize in the AR treatment, or perhaps the tillage in the CT treatment allowed for a higher rate of mineralization of nitrogen in the soil, which was available to the maize during the growing season. Additional research is needed to confirm the findings in this study and better understand some of the effects that require longer term evaluation.

\section{Acknowledgements}

This study would not have been possible without the cooperation of Holscher Farms, who provided all equipment and inputs for this study.

\section{Funding}

This work was funded in part by USDA NIFA Hatch Project \# ILLU-741-387.

\section{Conflicts of Interest}

The authors declare no conflicts of interest regarding the publication of this paper.

\section{References}

[1] Francis, G.S., Bartley, K.M. and Tabley, F.J. (1998) The Effect of Winter Cover Crop Management on Nitrate Leaching Losses and Crop Growth. The Journal of Agricultural Science, 131, 299-308. https://doi.org/10.1017/S0021859698005899

[2] Shepherd, M.A. (1999) The Effectiveness of Cover during Eight Years of a UK Sandland Rotation. Soil Use and Management, 15, 41-48. https://doi.org/10.1111/j.1475-2743.1999.tb00062.x

[3] Rasse, D.P., Ritchie, J.T., Peterson, W.R., Weil, J. and Smucker, A.J.M. (2000) Rye Cover Crop and Nitrogen Fertilization Effects on Nitrate Leaching in Inbred Maize Fields. Journal of Environmental Quality, 29, 298-304. https://doi.org/10.2134/jeq2000.00472425002900010037x

[4] Kaspar, T.C., Radke, J.K. and Laflen, J.M. (2001) Small Grain Cover Crops and Wheel Traffic Effects on Infiltration, Runoff, and Erosion. Journal of Soil and Water Conservation, 56, 160-164. https://doi.org/10.31274/icm-180809-706

[5] Fageria, N.K., Baligar, V.C. and Bailey, B.A. (2005) Role of Cover Crops in Improving Soil and Row Crop Productivity. Communications in Soil Science and Plant Analysis, 36, 2733-2757. https://doi.org/10.1080/00103620500303939

[6] Daniel, J.B., Abaye, A.O., Alley, M.M., Adcock, C.W. and Maitland, J.C. (1999) 
Winter Annual Cover Crops in a Virginia No-Till Cotton Production System. II. Cover Crop and Tillage Effects on Soil Moisture, Cotton Yield, and Cotton Quality. Journal of Cotton Science, 3, 84-91. https://doi.org/10.17660/ActaHortic.1999.504.10

[7] Dale, V.H., Kling, C.L., Meyer, J.L., Sanders, J., Stallworth, H., Armitage, T., Wangsness, D., et al. (2010) Hypoxia in the Northern Gulf of Mexico. Springer, New York, 9-51.

[8] Kapoor, A. and Viraraghavan, T. (1997) Nitrate Removal from Drinking Water-Review. Journal of Environmental Engineering, 123, 371-380. https://doi.org/10.1061/(ASCE)0733-9372(1997)123:4(371)

[9] Robertson, G.P. and Grace, P.R. (2004) Greenhouse Gas Fluxes in Tropical and Temperate Agriculture: The Need for a Full-Cost Accounting of Global Warming Potentials. In: Wassmann, R. and Vlek, P.L.G., Eds., Tropical Agriculture in Transition-Opportunities for Mitigating Greenhouse Gas Emissions? Springer, Dordrecht, 51-63. https://doi.org/10.1007/978-94-017-3604-6_3

[10] Sustainable Agriculture Research and Education (SARE) Outreach (2007) Managing Cover Crops Profitably. Third Edition, Sustainable Agriculture Research and Education Program, College Park, MD, 9-32.

[11] Illinois Environmental Protection Agency, Illinois Department of Agriculture, \& University of Illinois Extension (2015) Illinois Nutrient Loss Reduction Strategy. Illinois Environmental Protection Agency and Illinois Department of Agriculture. University of Illinois Extension, Urbana, IL, 8-34.

[12] Randall, G., Vetsch, J. and Huffman, J. (2003) Nitrate Losses in Subsurface Drainage from a Corn-Soybean Rotation as Affected by Time of Nitrogen Application and Use of Nitrapyrin. Journal of Environmental Quality, 32, 1764-1772. https://doi.org/10.2134/jeq2003.1764

[13] Ma, B., Dwyer, L.M. and Gregorich, E.G. (1999) Soil Nitrogen Amendment Effects on Nitrogen Uptake and Grain Yield of Maize. Agronomy Journal, 91, 650-656. https://doi.org/10.2134/agronj1999.914650x

[14] Moll, R., Kamprath, E. and Jackson, W. (1982) Analysis and Interpretation of Factors Which Contribute to Efficiency of Nitrogen Utilization. Agronomy Journal, 74, 562-564. https://doi.org/10.2134/agronj1982.00021962007400030037x

[15] Camberato, J., Nielsen, R. And Joern, B. (2014) Nitrogen Management Guidelines for Corn in Indiana. Applied Crop Research Update.

http://www.agry.purdue.edu/ext/corn/news/timeless/NitrogenMgmt.html

[16] USDA National Agricultural Statistics Service (2012) Census of Agriculture. http://www.agcensus.usda.gov/Publications/2012/.

[17] King, K.W., Fausey, N.R. and Williams, M.R. (2014) Effect of Subsurface Drainage on Streamflow in an Agricultural Headwater Watershed. Journal of Hydrology, 519, 438-445. https://doi.org/10.1016/j.jhydrol.2014.07.035

[18] King, K.W., Williams, M.R. and Fausey, N.R. (2015) Contributions of Systematic tile Drainage to Watershed-Scale Phosphorus Transport. Journal of Environmental Quality, 44, 486-494. https://doi.org/10.2134/jeq2014.04.0149

[19] King, K.W., Williams, M.R., Macrae, M.L., Fausey, N.R., Frankenberger, J., Smith, D.R., Kleinman, P.J. and Brown, L.C. (2015) Phosphorus Transport in Agricultural Subsurface Drainage: A Review. Journal of Environmental Quality, 44, 467-485. https://doi.org/10.2134/jeq2014.04.0163

[20] Ruffatti, M.D., Roth, R.T., Lacey, C.G. and Armstrong, S.D. (2019) Impacts of Nitrogen Application Timing and Cover Crop Inclusion on Subsurface Drainage Wa- 
ter Quality. Agricultural Water Management, 211, 81-88. https://doi.org/10.1016/j.agwat.2018.09.016

[21] Drury, C.F., Tan, C.S., Welacky, W.D., Reynolds, W.D., Zhang, T.Q., Oloya, T.O., McLaughlin, N.B. and Gaynor, J.D. (2014) Reducing Nitrate Loss in Tile Drainage water with Cover Crops and Water-Table Management Systems. Journal of Environmental Quality, 43, 587-598. https://doi.org/10.2134/jeq2012.0495

[22] David, M., McIsaac, G., Czapar, G., Schnitkey, G. and Mitchell, C. (2013) Science Assessment to Support an Illinois Nutrient Loss Reduction Strategy. University of Illinois, College of Agricultural, Consumer, and Environmental Sciences, Urbana, IL, 33-45.

[23] Kaspar, T.C., Jaynes, D.B., Parkin, T.B. and Moorman, T.B. (2007) Rye Cover Crop and Gamagrass Strip Effects on $\mathrm{NO}_{3}$ Concentration and Load in Tile Drainage. Journal of Environmental Quality, 36, 1503-1511.

https://doi.org/10.2134/jeq2006.0468

[24] Strock, J.S., Porter, P.M. and Russelle, M.P. (2004) Cover Cropping to Reduce Nitrate Loss through Subsurface Drainage in the Northern US Corn Belt. Journal of Environmental Quality, 33, 1010-1016. https://doi.org/10.2134/jeq2004.1010

[25] Basche, A.D., Kaspar, T.C., Archontoulis, S.V., Jaynes, D.B., Sauer, T.J., Parkin, T.B. and Miguez, F.E. (2016) Soil Water Improvements with the Long-Term Use of a Winter Rye Cover Crop. Agricultural Water Management, 172, 40-50. https://doi.org/10.1016/j.agwat.2016.04.006

[26] Tollenaar, M.M., Mihajlovic, M. and Vyn, T.J. (1993) Corn Growth Following Cover Crops: Influence of Cereal Cultivar, Cereal Removal and Nitrogen Rate. Agronomy Journal, 85, 251-255. https://doi.org/10.2134/agronj1993.00021962008500020017x

[27] Martinez, J. and Guiraud, G.A. (1990) Alysimeter Study of the Effects of a Ryegrass catch Crop during a Winter Wheat/Maize Rotation, on Nitrate Leaching and on the Following Crop. Journal of Soil Science, 41, 5-16. https://doi.org/10.1111/j.1365-2389.1990.tb00040.x

[28] Francis, G.S., Bartley, K.M. and Tabley, F.J. (1998) The Effect of Winter Cover Crop Management on Nitrate Leaching Losses and Crop Growth. The Journal of Agricultural Science, 131, 299-308. https://doi.org/10.1017/S0021859698005899

[29] Wyland, L.J., Jackson, L.E. and Schulbach, K.F. (1995) Soil Plant Nitrogen Dynamics Following Incorporation of a Mature Rye Cover Crop in a Lettuce Production System. The Journal of Agricultural Science, 124, 17-25. https://doi.org/10.1017/S0021859600071203

[30] Cochran, C.C. and Werner, S.E. (2007) Soil Survey of Crawford County, Illinois. United States Department of Agriculture National Resource Conservation Service, Washington DC, 1-11.

[31] Sawyer, J., Nafziger, E., Randall, G., Bundy, L., Rehm, G. and Joern, B. (2006) Concepts and Rationale for Regional Nitrogen Rate Guidelines for Corn. Extension and Outreach Publications, Iowa State University, Ames, IA, 1-28.

[32] Tonitto, C., David, M.B., Drinkwater, L.E. and Li, C. (2017) Applications of the DNDC Model to Tile-Drained Illinois Agroecosystems: Model Calibration, Validation, and Uncertainty Analysis. Nutrient Cycling in Agroecosystems, 78, 51-63. https://doi.org/10.1007/s10705-006-9076-0

[33] Gentry, L.E., David, M.B., Below, F.E., Royer, T.V. and McIsaac, G.F. (2009) Nitrogen Mass Balance of a Tile-Drained Agricultural Watershed in East-Central Illinois. Journal of Environmental Quality, 38, 1841. https://doi.org/10.2134/jeq2008.0406 